\title{
Effectiveness of a Communication Skills training program for medical students to identify psychosocial clues
}

\section{Authors:}

Roger Ruiz Moral,

School of Medicine, Universidad Francisco de Vitoria (Madrid). Córdoba University, Instituto Maimónides de Investigación Biomédica de Córdoba (IMIBIC), Córdoba. Spain

\section{Cristina Andrade-Rosa,}

Department of Primary Care, Los Castillos Health Centre. Alcorcón (Madrid). Spain

\section{Juan D Molina Martín,}

Villaverde Mental Health Centre. Department of Psychiatry, -Hospital 12 de Octubre (Madrid). Spain

\section{Emilio Cervera Barba,}

School of Medicine, Universidad Francisco de Vitoria (Madrid). Spain

\section{Luis Pérula de Torres,}

Córdoba University, Instituto Maimónides de Investigación Biomédica de Córdoba (IMIBIC). Department of Primary Care Córdoba. Spain

\section{Diana Monge Martín,}

School of Medicine, Universidad Francisco de Vitoria (Madrid). Spain

\section{Corresponding author at:}

Roger Ruiz Moral

School of Medicine, Universidad Francisco de Vitoria

Ctra M-515, Pozuelo-Majadahonda, Km 1,800

28223 Pozuelo de Alarcón (Madrid). Spain

Tel: 34695649759

\section{r.ruiz.prof@ufv.es}

'Declarations of interest: none' 


\begin{abstract}
Objective: This study explores whether an Experiential Training Programme (ETP) in communication skills (CS) improves students' ability to identify patients clues compared to those who follow a non-experiential training throughout their medical studies.
\end{abstract}

Method: Intervention Group (IG): 85 4th-year medical students who received the ETP and Control Group (CG): 67 recently graduated students who did not receive it. Their immediate (written) response was requested to three expressions offered by patients containing communicative clues. The answers were grouped into 2 categories: Clue recognised and response patient-centred and the opposite. Three researchers analysed the answers.

Results: Responses 366 (65 from the CG and 77 from the IG): 280 did not recognise clues: 131 (62\%) in CG and 149 (96\%) in IG and 86 recognised them: $80(37.9 \%)$ in IG and $6(3.9 \%)$ in CG ( $p=0.000)$. Some clues were more elusive than others $(p=0,003)$.

Conclusions: The students who received the ETP in CS showed greater ability to explore patients perspective taking advantage of different types of psychosocial clues than those who did not receive it in a non-relational context.

Practice implications: Further research is needed to assess whether this ability is maintained in simulated or real clinical situations.

Key words: Communication skills, Experiential learning, medical students, patient-physician relationship, biopsychosocial

This research did not receive any specific grant from funding agencies in the public, commercial, or not-for-profit sectors 


\section{Introduction}

Since Balint defined patient expressions describing the significance they give to their symptoms as "offers" (1), work has been carried out on identifying the different methods, behaviours or expressions patients use to convey this personal and contextual perspective. These include different types of body movements and facial expressions (2); verbal expressions which show dissatisfaction with previous healthcare experiences, or reluctance to follow a particular piece of advice or treatment. They also deal with speech censorship as an indicator of doubts, generalisations, omissions and also address certain types of visits, such as those without suitable justification; occasions when the patient interrupts the doctor; comments made at the end of the consultation which lead to a new consultation, and so on. (3-5). Lang et al reviewed clinical interviews over a period of 20 years and developed a taxonomy of what they called "clues", subsequently refined with the patients after the visits (6). When the doctor recognises and explores them, it conveys respect and interest towards the patient and has also been associated with positive results in consultations (7). Doctors, however, frequently tend to miss them which ultimately affects the physicianpatients relationship $(8,9)$. However, specific training in communication improves students' ability to recognise the clues and suitably adapt their approach to taking in the patient's point of view $(10,11)$.

The aim of this study was to assess the ability to detect and explore "communicative clues" offered via written statements or descriptions of clinical situations in fourth-year medical students who took part on an experiential training programme in clinical communication (CC) compared to students who had recently finished their medical degree without receiving this type of training. 


\section{Methods}

\subsection{Participants}

The intervention group (IG) were 85 fourth year medical students (70 females) from a single medical school who received the experiential training programme, the control group (CG), 65 (50 females) recently-graduated students not formally trained in $\mathrm{CC}$, who had not yet started their family medicine residency training in two Teaching Units.

\subsection{Communication Skills Training Programme}

The course structure, components and activities were described elsewhere (11)

\subsection{Data collection}

We modified the classification by Lang et al (6) on "communication clues" and choose a set of situations and expressions frequently used by patients in our context (table 1).

Table 1: Clues categories and examples

\begin{tabular}{|c|c|}
\hline Category & Example \\
\hline $\begin{array}{l}1.1 \text { Expressing } \\
\text { feelings directly (4). }\end{array}$ & $\begin{array}{l}\text { "The truth is, l'd like to do something about my weight. I'm really, } \\
\text { really worried about my weight; I feel bloated" }\end{array}$ \\
\hline $\begin{array}{l}1.2 \text { Expressing } \\
\text { feelings in denial or } \\
\text { projecting them (5). }\end{array}$ & $\begin{array}{l}\text { "Good morning doctor, l'm here because my wife has been nagging } \\
\text { me to tell you about these headaches I've been having. I'm not } \\
\text { particularly worried about them, as l've told her, but because she's } \\
\text { worried, I thought, well, let's go to the doctor and put her mind at } \\
\text { rest!" }\end{array}$ \\
\hline $\begin{array}{l}\text { 2.1 Discursive clues: } \\
\text { repetition (1) }\end{array}$ & $\begin{array}{l}\text { "He was very lethargic all day yesterday; he didn't feel like doing } \\
\text { anything. I've never noticed him like that before, it felt as if he was } \\
\text { lethargic, he hardly played, he often didn't take any notice when I was } \\
\text { talking to him; he didn't eat badly but, I don't know, I thought he was } \\
\text { lethargic" }\end{array}$ \\
\hline $\begin{array}{l}\text { 2.2 Discursive clues: } \\
\text { language censorship } \\
\text { (2) }\end{array}$ & $\begin{array}{l}\text { "... And above all, the frequency with which I have this discomfort } \\
\text { urinating, sometimes up to three or four times a month... My husband } \\
\text { doesn't understand, but that's how it is and I can't associate it with } \\
\text { anything, I'm careful not to get cold..." }\end{array}$ \\
\hline $\begin{array}{l}\text { 2.2 Discursive clues: } \\
\text { language censorship } \\
\text { (3) }\end{array}$ & $\begin{array}{l}\text { "The swelling keeps appearing, it's not completely gone away, nor } \\
\text { has the discomfort. The other day, I was here and a new doctor saw }\end{array}$ \\
\hline
\end{tabular}




\begin{tabular}{|c|c|}
\hline & $\begin{array}{l}\text { me, he was very kind but I think he was in a bit of a hurry, he gave } \\
\text { me some tablets and said to come back if I didn't improve" }\end{array}$ \\
\hline $\begin{array}{l}\text { 2.3 Discursive clues: } \\
\text { exaggerations (6) }\end{array}$ & $\begin{array}{l}\text { "This back pain is killing me and it's been so long since I noticed even } \\
\text { the slightest improvement..." }\end{array}$ \\
\hline $\begin{array}{l}\text { 3.1 Attempt to } \\
\text { understand or } \\
\text { explain the } \\
\text { symptoms: } \\
\text { expressing difficulty } \\
\text { (7) }\end{array}$ & $\begin{array}{l}\text { "Well, now you've seen it, just as I can see it, and no matter how } \\
\text { much I look at it, I don't know what it could be" }\end{array}$ \\
\hline $\begin{array}{l}\text { 3.2 Attempt to } \\
\text { understand or } \\
\text { explain the } \\
\text { symptoms: } \\
\text { Description of an } \\
\text { unmentioned } \\
\text { disorder (8) }\end{array}$ & $\begin{array}{l}\text { "...You see doctor, it's not that this cough is serious, it's just that it } \\
\text { never goes, it always comes back. I start to improve after taking the } \\
\text { medicine I bought, but it comes back. The phlegm when I cough is } \\
\text { clear, although recently, I think I have seen a few specks of blood" }\end{array}$ \\
\hline $\begin{array}{l}\text { 3.3 Attempt to } \\
\text { understand or } \\
\text { explain the } \\
\text { symptoms: } \\
\text { Questions with a hint } \\
\text { of courage (9) }\end{array}$ & $\begin{array}{l}\text { "...And one more thing doctor, l've heard that hypoglycaemia can } \\
\text { affect the brain. Is that right?" }\end{array}$ \\
\hline $\begin{array}{l}\text { 4. Sharing personal } \\
\text { history (10) }\end{array}$ & $\begin{array}{l}\text { "Do you know that my mother lived to be } 85 \text { ? I was the one who took } \\
\text { care of her right until the end, as my sisters live far away. She always } \\
\text { said that she didn't want to suffer because of it. It's what she always } \\
\text { told the doctor, and to be honest, she didn't seem to suffer. That was } \\
\text { a relief for me" }\end{array}$ \\
\hline $\begin{array}{l}\text { 5. Reluctance to } \\
\text { accept } \\
\text { recommendations } \\
\text { (11) }\end{array}$ & $\begin{array}{l}\text { "I'm not really sure that this is going to get rid of all my discomfort, but } \\
\text { we can give it a try" }\end{array}$ \\
\hline
\end{tabular}

The students were invited to take part in the study and, once their consent had been obtained, at the end of their normal teaching session, they were offered at random and in writing, three statements made by patients in a consultation which contained some type of communicative clue (table 1). They were asked to respond to the question: "What would your immediate response be to this patient?" They had six minutes to respond.

\subsection{Coding procedure and reliability}

After a prior review of 50 responses, the assessors (two GPs and a psychiatrist [CA, RRM, JM]) identified the different types of responses and grouped them into four subcategories divided into another two broader categories: 
A) Clue not recognised and not patient-centred response (NPC). This category included two types of response: A.1. Directed to exploring or verifying medical hypotheses, generally through closed-ended question, "have you had fever?"; open-ended focused question, "what else have you noticed?"; or describing an action, "let's see if we can see anything". A.2. directed at offering solutions or conveying premature comprehension: "Don't worry", "I understand", "what you're telling me is normal".

B) Clue recognised and patient-centred response (PC), which also has two responses: B.1. Directly aimed at reacting to the clue in order to clarify it, "what do you mean when you say...?"; and B.2. Directed at exploring patient's perspective (their idea or concern): "Is there anything in particular which worries you?"

Subsequently, inter-assessor reliability was analysed in a randomised subsample of 24 students who responded to 66 situations with different types of clues using Cohen's kappa (the two response categories), observer A versus $B=0.93$, $A$ versus $C=1$ and $B$ versus $C=0.93$; and the Friedman test (the four response subcategories $)(p=0.051)$.

Finally, responses were divided into three groups and distributed among raters for coding. A descriptive analysis was made and groups were compared according to the main dependent variable (type of communication training) and result independent variable (number of clues detected) using $X^{2}$ test.

\section{Results}

Finally, 142 students took part: 65 in the CG and 77 in the IG. Of the first, 49 (75.4\%) stated that they had received some type of CC training, most of which 
came in classes/seminars on special courses and practical observation. The rest had not received any type of training. Valid responses: 366, obtained from the 11 proposed situations: 146 for "discursive clues", 89 for "understanding and explaining the symptoms", 67 for "expressing feelings", 31 for "telling a personal history", and 33 for "showing disagreement or reluctance." Of all responses, 280 did not recognise the clue and were NPC, 131 (62\%) in the IG and 149 (96\%) in the CG. In 86 cases, the clue was recognised and the responses were PC: 80 $(37.9 \%)$ in the IG and $6(3.9 \%)$ in the $C G\left(X^{2}: 57.612 p=0.000\right)$ (figure 1). Figure 2 shows the distribution of responses from fourth-year students in each of the five clues categories. The most recognised clues were: repetition in discourse (16; $76.2 \%$ ), direct expression of feelings $(11 ; 52.4 \%)$, showing reluctance or disagreement $(9 ; 50 \%)$ and affirming difficulty in understanding the symptoms $(7$; $41.2 \%)$. The most elusive clues were: description of the symptoms with an effort to understand them $(14 ; 87.5 \%)$, direct question as an expression for understanding the disorder (13; 81.3\%) and exaggeration in the discourse (16; $76.2 \%)$. There were differences in the degree of recognition of clues according to their nature $\left(X^{2}: 26.728 ; p=0.003\right)$.

\section{Discussion and conclusion}

\subsection{Discussion}

The students who received the experiential training programme showed a greater ability to identify the situations provided as clues, directing their initial investigation towards clarifying the perspective of the patient, trying to discover the meaning of the clue or directly asking about their ideas or concerns. In this way, the patient had the chance to explain any possible hidden agenda. In clinical 
practice, the awareness and exploration of this type of clue shows active listening and generally conveys the doctor's interest in the patient, strengthening the clinical relationship $(7,12)$. In a simultaneous study with the same students, this training, which included behavioural and attitudinal aspects, increased their ability to empathise using different communicative skills. Among those, was the identification and follow-up of communicative clues in simulated patient interviews (11). What this study shows is that the students who received the training identified more communicative clues than those who didn't, although these clues were presented in a theoretical context rather than a relational one, in the form of briefly defined situations in written text, to which students had to offer a quick written response. However, this approach can be complimentary to that shown by students in their simulated interviews, highlighting the level of development of students' attention and clinical thinking, showing the "patientcentred medicine" logic as that developed by experienced doctors in real practice $(13,14)$ and which the training programme would encourage.

Our students also identified some clues more easily than others, which also happens in real situations probably due to the student's skills, the time available or the way in which the situations are described. However, given the way these clues are presented in this study, isolated from any other type of "contextual interference", the results offer information regarding the inherent difficulty in identifying and exploring each of the clues. Different authors have studied the types of clues patients provide $(3,7,8)$ and the doctors $(8,15)$ or students $(10,11)$ responses, but there is little information regarding the reasons why some clues are more easily and quickly recognised than others. Factors such as the number, order or form in which the clues are presented can influence this (10). Maybe 
what our study highlights is the greater or lesser difficulty recognising the clue itself, which is useful for the design and planning of training scenarios: in simulated scenarios with students or beginners using clues too subtle may have a lower educational impact than desired or even become counter-productive $(16,17)$.

Limitations: next step would be to verify the efficacy of the programme in real or simulated practice conditions compared to other educational strategies. This study only includes a sample of clues, although they are very frequent in practice, with other significant factors left unexplored, in particular non-verbal clues. This comparison was performed on a group of students of different level. We do not know if two years later, this ability to detect and explore clues will be maintained.

\subsection{Conclusion}

A training programme in patient-physician communication with experiential characteristics increases the students awareness of communicative clues and their exploration through questions in written simulated situations. Some clues are more elusive than others.

\subsection{Practice implications}

These results show the need to check this efficacy in a real or simulated relational context and they allow us to classify clues for teaching scenarios depending on their greater or lesser difficulty.

Funding: This research did not receive any specific grant from funding agencies in the public, commercial, or not-for-profit sectors 


\section{References}

1. Balint M. The doctor, his patient and the illness. London: Churchill Livingnstone, 2000

2. Elkman P, Friesen WV. The repertoire of non verbal behavior: categories, origin, usages and coding. Semiotica, 1969;1:49-98

3. Neighbour R. The Inner Consultation: How to Develop an Effective and Intuitive Consulting Style. Lancaster, England: MTP Press Ltd; 1987:164178.

4. Butler CC. The "maternal grimace" sign: a clue to the importance of the contextual diagnosis. Arch Fam Med. 1995;4:273-5.

5. Realini T, Kalet A, Sparling J. Interruption in the medical interaction. Arch Fam Med. 1995;4:1028-1033

6. Lang F, Floyd M, Beine KL. Clues to patients' explanations and concerns about their illness: a call for active listening. Arch Fam Med 2000;9:222-7

7. Lang F, Floyd MR, Beine KL, Buck P. Sequenced questioning to elicit the patient's perspective on illness: effects on information disclosure, patient satisfaction, and time expenditure. Fam Med. 2002 May;34:325-30.

8. Levinson W, Gorawara-Bhat R, Lamb J. A study of patient clues and physician responses in primary care and surgical settings. J Amer Med Assoc 2000;284:1021-7

9. Zimmermann C, Del Piccolo L, Finset A. Cues and concerns by patients in medical consultations: a literature review. Psychol Bull. 2007;133, 43863 
10. Thompson BM, Teal CR, Scott SM, Manning SN, Greenfield E, Shada R, Haidet P. Following the Clues: Teaching Medical Students to Explore Patients' Contexts. Patient Educ Couns 2010;80:345-50

11. Ruiz-Moral R, Pérula de Torres LA, Monge D, García Leonardo C, Caballero F. Teaching medical students to express empathy by exploring patient emotions and experiences in standardized medical encounters. Patient Educ Couns 2017;100;1694-1700

12. Eide H, Sibbern T, Egeland T, Finset A, Johannessen T, Miaskowski C, Rustøen T. Fibromyalgia Patients' Communication of Cues and Concerns: Interaction Analysis of Pain Clinic Consultations. Clinical J Pain. 2011; 27:602-10

13. Fuks A, Boudreau JD, Cassell EJ. Teaching clinical thinking to first-year medical students. Med Teach 2009;31:105-111.

14. Kempster PA. Looking for clues. J Clin Neurosci 2006;13(2):178-80.

15. Bonvicini KA, Perlin MJ, Bylund CL, Carroll G, Rouse RA, Goldstein MG. Impact of communication training on physician expression of empathy in patient encounters. Patient Educ Couns 2009;75:3-10

16. Ruiz-Moral R, García de Leonardo C, Caballero Martínez F, Monge Martínez D. Medical students' perceptions towards learning communication skills: a qualitative study following the 2-year training programme. Int J Med Edu 2019;10:90-97

17. Benbassat J, Baumal R. What is empathy, and how can it be promoted during clinical clerkships? Academic Med 2004;79: 832-9. 